\title{
ANTIBODY RESPONSES IN ACUTE AND CHRONIC Q FEVER AND IN SUBJECTS VACCINATED AGAINST $Q$ FEVER
}

\author{
D. WORSWICK AND B. P. MARMION
}

\section{Division of Medical Virology, Institute of Medical and Veterinary Science, Box 14 Rundle Mall P.O., Adelaide. S.A. 5000, Australia}

\begin{abstract}
Summary. An analysis is made of the antibody response to Coxiella burneti Phase- 1 and Phase- 2 antigens, as measured by immunofluorescence in the IgM, IgG or IgA immunoglobulin classes, or by complement-fixation, in patients with acute and chronic $Q$ fever and in vaccinated or skin-tested subjects. In acute (primary) $Q$ fever, IgM specific antibodies to Phase- 1 antigen are present in early convalescence together with $\operatorname{IgM}, \mathrm{IgG}, \mathrm{IgA}$ and $\mathrm{CF}$ antibodies to Phase- 2 antigen. IgM specific antibody may persist for at least 678 days after onset of the acute illness. Patients with chronic Q fever have no IgM specific antibody to Phase- 1 or -2 antigens, or only at very low levels; high levels of specific antibody in the $\mathrm{IgG}$ and $\mathrm{IgA}$ classes, together with $\mathrm{CF}$ antibody to both antigenic phases, appear to be characteristic. The serological response in initially seronegative, vaccinated subjects is mainly to Phase-1 antigen in the IgM fraction, and to a lesser degree to Phase- 2 antigen by CF and in IgM and IgG classes. Subjects who were equivocally seropositive before vaccination showed IgA and IgG specific antibody responses to Phase-1 antigen and $\mathrm{CF}$ and IgG class responses to Phase-2 antigen. Similar antibody profiles were observed in patients who seroconverted after a positive skin-test. Data are also presented on the suitability of $C$. burneti antigens for use in immunofluorescence and on the binding of IgM specific antibody by Phase- 1 antigen but its failure to fix complement.
\end{abstract}

\section{INTRODUCTION}

A clinical diagnosis of acute $Q$ fever is mostly confirmed in the laboratory by the demonstration of an increase of antibody between a serum specimen taken at or within a few days of the onset of illness ("acute phase serum") and one taken in convalescence ("convalescent phase serum"). Isolation of the organism in guinea-pigs or hamsters is expensive, slow and potentially hazardous to unvaccinated laboratory staff. Consequently it is rarely used except in special circumstances (e.g., diagnosis of chronic $\mathrm{Q}$ fever endocarditis or hepatitis).

The serological technique commonly used is the $\mathrm{Q}$ fever complement fixation test (CFT); antigens are available commercially and it fits conveniently with the battery of $\mathrm{CF}$ tests used routinely in the virus laboratory. Although well tried and specific, the $\mathrm{Q}$ fever CFT has a number of limitations. The CF antibody develops slowly and is 
predominantly to Phase-2 antigen; low levels of Phase-1 CF antibody may, from time to time, be observed in late convalescence.

Some authors have claimed that a minority of Q-fever cases diagnosed on clinical and epidemiological grounds fail to develop CF antibody or develop it very late in the disease (Buckley, 1980). This may reflect a delay in antibody formation in antibiotictreated cases, or a variation in the balance of antibody response in different immunoglobulin classes, or, conceivably, technical factors related to the antigen concentration used in the CF test. Finally, there is the problem of interpreting a raised, unchanging level of CF antibody in the convalescent-phase serum of a patient who has had an illness resembling $Q$ fever. Strictly speaking, the antibody might result either from the current infection or, if in the intermediate range of titre distribution (40-80), it might represent persisting antibody from a past infection. In attempts to resolve this ambiguity, the CF test has been adapted to measure IgM and IgG specific antibody, either by treatment of sera with ethanethiol to inactivate $\operatorname{IgM}$ and absorption with Staph. aureus protein A to remove IgG as practised with guinea-pig antisera by Tokarevich et al. (1980), or by density gradient separation of the two immunoglobulin classes in human antisera (Murphy and Magro, 1980). These approaches are effective but labour intensive.

A wide variety of other serological tests have been described for Q fever and used on a limited scale in the past. These include: $C$. burneti agglutination in tubes (Lennette et al., 1952); or on slides (Giroud and Giroud, 1944; Babudieri, 1958); capillary tube agglutination (Luoto, 1956); radioisotope precipitation (Lackman et al., 1964; Tabert and Lackman, 1965; McKiel and Millar, 1968); micro-agglutination (Fiset et al., 1969); agglutination resuspension (Ormsbee, 1964); and mouse protection (Abinanti and Marmion, 1957). The variants of the agglutination test give results broadly comparable with those of the CFT but may become positive earlier in the disease. Radioisotope precipitation is highly sensitive and is more suitable for epidemiological surveys and for the measurement of antibody response after vaccination than for the routine diagnosis of cases. Mouse protection tests are laborious but are a very sensitive indicator of the presence of Phase-1 antibody.

A more recent and attractive development for $\mathrm{Q}$ fever serodiagnosis employs indirect immunofluorescence (IF) with $C$. burneti Phase-1 and -2 suspensions, combined with immunoglobulin-class-specific conjugates. Goldwasser and Shepard (1959) used IF to differentiate murine and epidemic typhus serologically, and Halevy and Goldwasser (1972) used it to differentiate C. burneti Phase 1 and 2. Bozeman and Elisberg (1963) and Elisberg and Bozeman (1966) extended the IF test to Q fever, scrub typhus and Rocky Mountain spotted fever. The technique was further modified to the micro IF technique used by Wang (1971) for chlamydia antibody in which a diluted serum is placed over a microdot of organisms fixed to a microscope slide. This microdot or microimmunofluorescence method has been used with various species of rickettsia including Rocky Mountain Spotted Fever (Philip et al., 1976). It also has the advantage that it permits economical analysis of the various immunoglobulin classes of antibody involved in the serological response of the patient. Recent descriptions of the use of $Q$ fever immunofluorescence tests with immunoglobulin class determinations include those of Kimbrough et al. (1979) and Peacock et al. (1983) with chronic Q fever and Murphy and Hunt (1981) and Hunt et al. (1983) with acute cases of Q fever. Finally, Halle, et al. (1977) used ELISA for detection of IgM and IgG specific antibody 
in epidemic and endemic typhus and Field, Hunt and Murphy (1983) have applied the method to $\mathrm{Q}$ fever.

During the period 1981-83 our laboratory has been conducting a trial of an inactivated $Q$ fever vaccine in the control of Q fever in two South Australian abattoirs. Complement fixation and IF tests have been used to measure antibody in acute and chronic $Q$ fever, and in vaccinated subjects. The findings differ in some respects from those reported above and so are described and critically discussed in relation to the earlier findings.

\section{MATERIALS AND METHODS}

Sera from patients with acute Q fever which were collected between 1980 and 1983 and the majority of those from patients with chronic $\mathrm{Q}$ fever were stored at $-20^{\circ} \mathrm{C}$. Those from vaccinees were stored at $4^{\circ} \mathrm{C}$ before testing.

Coxiella burneti antigens. (1) For immunofluorescence tests: Phase-1 and Phase- 2 antigens were kindly supplied by Dr M. Peacock, Rocky Mountain Laboratory, Hamilton, MT, USA. He stated that the Phase-1 antigen (referred to as RSA 531, Nine Mile below) was prepared from C. burneti, Nine Mile strain, passed 307 times in guinea-pigs, then cloned from primary chick-embryo cell culture plaques (one pass in tissue culture: 1TC) and passed twice in chick egg-yolk sac (RSA 531, Nine Mile 307 GP/1TC/2EP). Phase-2 antigens (RSA 516 and CBO 23, 24, 32, Nine Mile 90EP/1TC/4EP, clone 4) were from organisms that had been passed 90 times in chick egg yolk sacs (EP) and then plaqued once in chick-embryo cell culture. Several individual plaque populations were picked and cultured for four further passages in chick egg-yolk sacs to provide the Phase- 2 antigen. The population of organisms was entirely in Phase 2; on guinea-pig inoculation they did not cause infection or persist in the tissues.

(2) For complement fixation tests: Phase-1 and Phase-2 antigens were obtained from the Commonwealth Serum Laboratories, Melbourne, Victoria, Australia.

\section{Complement fixation test.}

Microtitre complement fixation tests were performed according to the method of Bradstreet and Taylor (1962). Q-fever antigens were titrated in 'chess board' fashion against known positive sera and an optimal concentration--i.e., that giving the highest antibody titre--was determined and four times this dose used for the test. Sera were inactivated and tested at a dilution of 1 in 2.5 in prevaccination 'screen' tests in healthy individuals. In suspected Q-fever cases the starting serum dilution was 1 in 5 .

\section{Micro-immunofluorescence test}

Test for rheumatoid factor ( $R F$ ). All the sera were first tested for RF. A $50 \mu$ l volume of $\gamma$-globulin-coated latex particles in suspension was mixed with an equal volume of absorbed patient's serum on black coated glass slides "Gonavi slide" (Mochida Pharmaceutical Co. Ltd, Tokyo 160, Japan) to check for RF. Those in which it was detected were absorbed with latex particles coated with human $\gamma$ globulin (Commonwealth Serum Laboratories, Melbourne, Australia). A volume of $0.25 \mathrm{ml}$ was sedimented at $2300 \mathrm{~g}$ for $30 \mathrm{~min}$ in V-bottomed, polypropylene tubes $(45 \mathrm{~mm} \times 5 \mathrm{~mm}$ diameter) and suspended in $0.25 \mathrm{ml}$ of patient's serum diluted 1 in 5 in phosphate-buffered saline (PBS) $p H$ 7.2. After incubation at room temperature for $1 \mathrm{~h}$ or overnight at $4{ }^{\circ} \mathrm{C}$, the latex particles were sedimented as before and the supernate was removed and retested for rheumatoid factor. If necessary the absorption procedure was repeated until all sera were RF negative. Sera for immunoglobulin class-specific antibody determination were absorbed for RF as a routine.

Preparation of slides. Teflon coated slides were prepared by placing each slide over a cardboard template, on to which had been punched 36 equally spaced holes (three rows of 12 holes). One small drop of glycerol was placed on the slide at a spot designated by the premarked 
template underneath the slide. The slide was then sprayed with Teflon. Several slides were stacked laterally in metal racks and the glycerol was removed by immersing the slides in a warm water and detergent solution. They were then rinsed in running tap water and finally in distilled water before being air-dried. Phase- 1 and Phase- 2 . burneti antigens were applied as microdots (100 dots $/ 10 \mu \mathrm{l}$ ) with a microsyringe; the rickettsial concentration was $200 \mu \mathrm{g} / \mathrm{ml}$ dry weight. Phase- 1 antigen was added to half of the 36 wells on the left portion of the slide and Phase-2 antigen to the remaining 18 wells on the right half of the slide. The microdots of antigen were dried, fixed in acetone at room temperature for $10 \mathrm{~min}$, and stored dry in black, airtight boxes at $4 \mathrm{C}$ for up to 3 days before use.

Fluorescent antibody staining. Serial two-fold dilutions of patient's sera from 10 to 320 were prepared in PBS containing normal yolk sac $1 \%$ and each dilution was carefully layered over a microdot of Phase-1 and Phase-2 antigen set out on each of three slides, to allow for detection of IgG, IgM and IgA specific antibody. Slides for the detection of IgG and IgA immunoglobulin class were incubated for $45 \mathrm{~min}$ at $37^{\circ} \mathrm{C}$, whereas slides for the detection of IgM were incubated for $2.5 \mathrm{~h}$ at $37^{\circ} \mathrm{C}$ which gave essentially the same results as overnight incubation at 4 C. Controls included (a) sera positive for IgM, IgG and IgA antibody to Phase- 1 and Phase-2 antigens, and (b) a serum negative for antibody to Phase- 1 and -2 antigens in all three immunoglobulin classes. Normal yolk sac $(1 \%)$ diluent controls were included in each batch of tests to check for antigen autofluorescence. After incubation, the diluted serum was removed from each slide with a gentle jet of PBS from a wash bottle; slides were then placed in metal racks and washed in two changes of PBS each lasting $10 \mathrm{~min}$. After drying, antigen microdots on each slide were overlaid with the appropriate fluorescein labelled anti-human $\operatorname{IgM}, \operatorname{IgG}$ or $\operatorname{IgA}$ conjugate and incubated for 30 min at $37^{\circ} \mathrm{C}$. They were washed as before, dipped quickly in distilled water, dried, mounted in glycerol $90 \%$ in PBS, $p \mathrm{H} 8.6$ and covered with a single large coverslip extended over the whole slide. Slides were examined within $6 \mathrm{~h}$ by means of a Zeiss fluorescent microscope (blue excitation filter BP455/490 and a barrier filter BP520-560) at $\times 400$ magnification with incident illumination. End points against each antigen (Phase-1 and Phase-2) were taken as the highest serum dilution that conferred definite fluorescence on the organisms.

Conjugates. $\mathrm{Mu}$ chain-specific rabbit anti-human IgM and $\mathrm{Fc}$-specific goat anti-human fluorescein labelled conjugates, obtained from Cappel Laboratories, Cochranville, PA, USA, were used for the detection of IgM and IgG antibodies respectively. For the IgA test, sheep anti-human IgA fluorescein-labelled globulin was purchased from Wellcome Laboratories, Beckenham, Kent. The appropriate dilution of each conjugate was determined by checkerboard titration against a positive antiserum and was used at twice the concentration of the optimum dilution.

Fractionation and removal of serum immunoglobulins. Patient's serum $(0 \cdot 4 \mathrm{ml})$ was absorbed with an equal volume of globulin-coated latex to remove RF and then centrifuged on $10-40 \%$ $\mathrm{w} / \mathrm{v}$ sucrose gradients adjusted to $\mathrm{pH} 2.6$ to dissociate any remaining complexes of specific antibody and RF. Fractions (arbitrarily called $\frac{1}{2}$ dilutions) were collected from the bottom of the tube and adjusted to $p \mathrm{H} \mathrm{7.3}$ with an equal volume of $0.015 \mathrm{~N} \mathrm{Na} \mathrm{OH}$. The presence of $\operatorname{IgM}, \operatorname{IgG}$ and $\operatorname{IgA}$ in each fraction was determined qualitatively on radial immunodiffusion plates (Behring AG, Marburg, West Germany). Fractions 2-4, collected early, contained IgM free of $\operatorname{IgG}$ and $\operatorname{IgA}$, while fractions 9-11, collected later, contained a mixture of $\operatorname{IgG}$ and $\operatorname{IgA}$.

To remove IgG, $0.1 \mathrm{ml}$ of the appropriate fraction mixture was absorbed with $0.05 \mathrm{ml}$ of rabbit anti-human IgG conjugate obtained from Dako Patts, Copenhagen, Denmark, (concentration $10 \mathrm{mg} / \mathrm{ml}$ ) and incubated at $37^{\circ} \mathrm{C}$ for $1 \mathrm{~h}$. After incubation, the mixture was centrifuged at $2300 \mathrm{~g}$ for $30 \mathrm{~min}$ and the supernate removed. The latter was again treated by adding a further $0.05 \mathrm{ml}$ of anti-human $\mathrm{IgG}$ conjugate until no further precipitate of antigen-antibody was present after centrifugation. The final supernate was then tested by radial immunodiffusion and microimmunofluorescence.

A similar volume of fractions was also included as an untreated control. Other classes of immunoglobulin-IgM and IgA-could also be removed by the same procedure and the appropriate anti-human conjugate from Dako Patts. 
TABLE I

Variation in commercially available C. burneti Phase-2 CF antigens as satisfactory reagents for the microimmunofluorescence test

\begin{tabular}{cc|ccccc}
\hline & \multicolumn{3}{|c}{ Titre of antibody in immunofluorescence test } \\
\cline { 3 - 7 } & & $\begin{array}{c}\text { Reference } \\
\text { antigens } \\
\text { (Nine Mile) } \\
\text { RMLab (USA) }\end{array}$ & $\begin{array}{c}\text { Supplier A } \\
\text { (Nine Mile) }\end{array}$ & \multicolumn{2}{c}{$\begin{array}{c}\text { Supplier B } \\
\text { (Nine Mile) }\end{array}$} \\
\cline { 3 - 7 } Serum & Class & Phase1* & Phase 2 & $\begin{array}{c}\text { Batch 2/81 } \\
\text { Phase 2 }\end{array}$ & $\begin{array}{c}\text { Batch 70/1 } \\
\text { Phase 2 }\end{array}$ & $\begin{array}{c}\text { Batch 72/1 } \\
\text { Phase2 }\end{array}$ \\
\hline A & IgM & 160 & $<10$ & $<10$ & 80 & 160 \\
B & IgM & 160 & $<10$ & $<10$ & 80 & 40 \\
C & IgM & 80 & $<10$ & $<10$ & 80 & 40 \\
D & IgG & 40 & $<10$ & $<10$ & 10 & 10 \\
E & IgA & $<10$ & 2560 & 2560 & 2560 & 2560 \\
\hline
\end{tabular}

RM Lab $=$ Rocky Mountain Laboratory.

* RSA 531, Nine Mile 307 GP/ITC/2EP.

$\dagger$ RSA 516, Nine Mile $90 \mathrm{EP} / \mathrm{ITC} / 4 \mathrm{EP}$.

\section{RESULTS}

Specificity of $C$. burneti antigen preparations as reagents for microimmunofluorescent detection of $C$. burneti Phase- 1 and -2 antibodies

Phase variation in $C$. burneti antigens was originally defined by the reactivity of preparations in complement fixation tests (Stoker and Fiset, 1956) and seems to be a host-controlled variation of the proportion of Phase- 1 and Phase- 2 organisms in the total population of rickettsiae. When the organism is multiplying in an intact animal (e.g., sheep, guinea-pig) any Phase-2 variants that develop have a poor survival value in the face of immune mechanisms and the population remains overwhelmingly in Phase 1. When passaged in the chick-embryo yolk sac, Phase- 2 variants are not eliminated and eventually, depending on the particular strain under study, replace the Phase-1 organisms. Depending on the degree of yolk-sac adaptation, it is possible to have a mixed population of Phase- 1 and -2 organisms that may be unsuitable for use in the microimmunofluorescence test (table I). The table shows that the reference $Q$ fever antigens from the Rocky Mountain Laboratory (RMF) gave a clear-cut differentiation of Phase-1 and Phase-2 IF antibody. Antigen from Supplier A for use in the CFT appeared to be totally in Phase 2 and did not react with the serum samples A-D that contained only Phase- 1 antibody. On the other hand, the antigens from Supplier B, also sold for use in the CFT, were unsatisfactory because although labelled Phase 2, they also reacted by IF with all Phase- 1 antisera tested and so, in fact, were a mixture of the two antigenic phases.

Specificity of fluorescein conjugates used to determine specific antibody in the three immunoglobulin classes

Table II shows the results obtained with sera from six patients with acute or primary $Q$ fever and two subjects without serological evidence of $Q$ fever infection. It will be seen that fractions 2-4 from patients A, B, C, D, E and F all showed IgM only by radial diffusion and also reacted solely with the anti-IgM conjugate and $C$. burneti 
TABLE II

Specificity of the anti-human fuorescein labelled conjugates for the detection of $Q$ fever specific $\operatorname{Ig} M, \operatorname{Ig} G$ and $\operatorname{Ig} A$ antibodies as demonstrated with sucrose density gradient fractions of selected patient sera

\begin{tabular}{|c|c|c|c|c|c|c|c|c|c|c|}
\hline \multirow[b]{3}{*}{ Patient } & \multirow{3}{*}{$\begin{array}{l}\text { Sucrose } \\
\text { fraction no. }\end{array}$} & \multicolumn{3}{|c|}{$\begin{array}{l}\text { Radial } \\
\text { immunodiffusion }\end{array}$} & \multicolumn{6}{|c|}{$\begin{array}{l}\text { Titre of antibody to } C \text {. burneti } \\
\text { Phase } 2 \text { by immunofluorescence }\end{array}$} \\
\hline & & \multirow[b]{2}{*}{ IgM } & \multirow[b]{2}{*}{ IgG } & \multirow[b]{2}{*}{ IgA } & \multicolumn{3}{|c|}{$\begin{array}{l}\text { Sucrose fractions } \\
\text { unabsorbed }\end{array}$} & \multicolumn{3}{|c|}{$\begin{array}{l}\text { Sucrose fractions } \\
\text { after absorption } \\
\text { of IgG }\end{array}$} \\
\hline & & & & & $\operatorname{IgM}$ & $\mathrm{IgG}$ & $\operatorname{Ig} \mathrm{A}$ & $\operatorname{IgM}$ & $\mathrm{IgG}$ & $\operatorname{IgA}$ \\
\hline $\begin{array}{l}\text { Acute } Q . \\
\text { A } \\
\text { B } \\
\text { C } \\
\text { D }\end{array}$ & $\begin{array}{r}\text { ver } \\
9 \\
9 \\
10 \\
11\end{array}$ & $\begin{array}{l}- \\
- \\
- \\
-\end{array}$ & $\begin{array}{l}++ \\
++ \\
++ \\
++\end{array}$ & $\begin{array}{l}++ \\
++ \\
++ \\
+\end{array}$ & $\begin{array}{l}<16 \\
<16 \\
<16 \\
<16\end{array}$ & $\begin{array}{r}256 \\
512 \\
256 \\
1024\end{array}$ & $\begin{array}{l}512 \\
128 \\
512 \\
512\end{array}$ & $\begin{array}{l}<16 \\
<16 \\
<16 \\
<16\end{array}$ & $\begin{array}{l}<16 \\
<16 \\
<16 \\
<16\end{array}$ & $\begin{array}{l}512 \\
128 \\
512 \\
256\end{array}$ \\
\hline $\begin{array}{l}\text { A } \\
\text { B } \\
\text { C } \\
\text { D }\end{array}$ & $\begin{array}{l}2 \\
2 \\
2 \\
2 \\
3 \\
4\end{array}$ & $\begin{array}{c}++ \\
++ \\
+ \\
+ \\
++ \\
+++\end{array}$ & $\begin{array}{l}- \\
- \\
- \\
- \\
- \\
-\end{array}$ & $\begin{array}{l}- \\
- \\
- \\
- \\
-\end{array}$ & $\begin{array}{r}256 \\
512 \\
128 \\
256 \\
2048 \\
4096\end{array}$ & $\begin{array}{l}<16 \\
<16 \\
<16 \\
<16 \\
<16 \\
<16\end{array}$ & $\begin{array}{l}<16 \\
<16 \\
<16 \\
<16 \\
<16 \\
<16\end{array}$ & $\begin{array}{l}\ldots \\
\ldots \\
\ldots \\
\cdots \\
\ldots \\
\ldots\end{array}$ & $\begin{array}{l}\ldots \\
\ldots \\
\ldots \\
\ldots \\
\ldots \\
\ldots\end{array}$ & $\begin{array}{l}\ldots \\
\ldots \\
\ldots \\
\ldots \\
\ldots \\
\ldots\end{array}$ \\
\hline $\mathrm{E}$ & $\begin{array}{r}3 \\
11\end{array}$ & + & - & $\overline{+}+$ & $\begin{array}{l}1024 \\
<16\end{array}$ & $\begin{array}{r}<16 \\
2048\end{array}$ & $\begin{array}{l}<16 \\
<16\end{array}$ & $\begin{array}{l}\ldots \\
\ldots\end{array}$ & $\begin{array}{l}\ldots \\
\ldots\end{array}$ & $\begin{array}{l}\ldots \\
\ldots\end{array}$ \\
\hline $\begin{array}{l}\mathrm{F} \\
\text { No } O \text { fev }\end{array}$ & $\begin{array}{r}3 \\
11\end{array}$ & $\stackrel{++}{+}$ & $\overline{+}+$ & $\dot{+}+$ & $\begin{array}{l}4096 \\
<16\end{array}$ & $\begin{array}{r}<16 \\
512\end{array}$ & $\begin{array}{l}<16 \\
<16\end{array}$ & $\begin{array}{l}\cdots \\
\cdots\end{array}$ & $\begin{array}{l}\cdots \\
\cdots\end{array}$ & $\begin{array}{l}\cdots \\
\cdots\end{array}$ \\
\hline G & $\begin{array}{r}2 \\
11\end{array}$ & $\begin{array}{c}+++ \\
-\end{array}$ & $\dot{+}+$ & + & $\begin{array}{l}<16 \\
<16\end{array}$ & $\begin{array}{l}<16 \\
<16\end{array}$ & $\begin{array}{l}<16 \\
<16\end{array}$ & $\begin{array}{l}\cdots \\
\cdots\end{array}$ & $\begin{array}{l}\cdots \\
\cdots\end{array}$ & $\begin{array}{l}\cdots \\
\cdots\end{array}$ \\
\hline $\mathrm{H}$ & $\stackrel{2}{11}$ & ++ & - & $\overline{+}+$ & $\begin{array}{l}<16 \\
<16\end{array}$ & $\begin{array}{l}<16 \\
<16\end{array}$ & $\begin{array}{l}<16 \\
<16\end{array}$ & $\begin{array}{l}\cdots \\
\cdots\end{array}$ & $\begin{array}{l}\cdots \\
\cdots\end{array}$ & $\begin{array}{l}\cdots \\
\cdots\end{array}$ \\
\hline
\end{tabular}

\section{$-=$ Negative.}

$\ldots=$ Not done.

Phase 2. Similarly, the higher fractions 9,10 or 11 from patients A, B, C and D contained IgG and IgA specific antibody; the IgG specific antibody could be absorbed with rabbit anti-human IgG leaving IgA specific antibody only. Fractionation of sera from patients $\mathrm{G}$ and $\mathrm{H}$ without $\mathrm{Q}$ fever gave good separation of total $\operatorname{IgM}$ on the one hand, and IgG and IgA on the other hand but with no specific antibody activity. It may be noted from table II that patients $\mathrm{E}$ and $\mathrm{F}$, who had IgM and IgG antibody to $C$. burneti Phase 2, but no IgA specific antibody, represent a minority (about $10 \%$ ) of cases of $\mathrm{Q}$ fever who do not show IgA specific antibody to C. burneti Phase 2 in early convalescence (see also fig. 1).

\section{Pattern of $C F$ and IF antibody responses in acute $Q$ fever}

Twenty-nine patients with acute $Q$ fever were studied. Sequential samples were available from a majority of these cases but there were some gaps in mid convalescence. Fig. 1 shows the results of testing samples from these acute cases of Q fever for Phase-1 and Phase-2 IF antibody in various immunoglobulin classes and also the results of CF tests. The findings are expressed as the proportion of patients who were positive for a particular type of antibody in relation to days from onset of illness. (A titre $\geqslant 5$ was considered positive in the CF test and $\geqslant 10$ in IF tests.) It will be seen that although the 


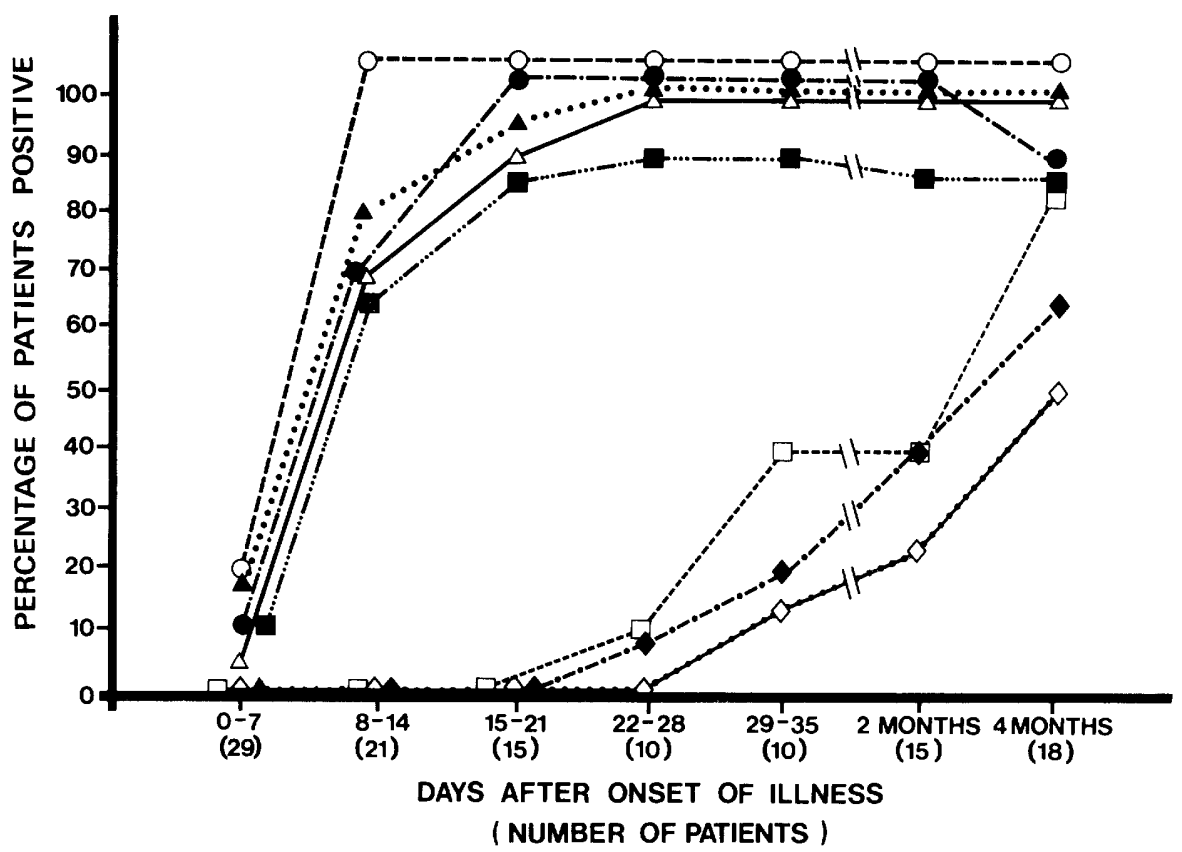

Fig. 1. -IgM, IgG, IgA and CF response to Q-fever Phase-1 and Phase-2 antigens in acute infection; $\diamond-\diamond$ Phase-1 CF, $\square-\ldots-\square$ Phase-1 IgG, -.-Phase-1 IgA, - - Phase-1 IgM, $\triangle \longrightarrow \triangle$ Phase-2 CF, ^... Phase-2 IgG, _...... Phase-2 IgA, O - O Phase 2 IgM.

CF test for antibody to Phase- 2 antigen was positive in $3 \%$ of patients sampled up to 7 days after onset, a low proportion, up to $20 \%$, of the patients already had IF antibodies in the various immunoglobulin classes and that the most frequent positive result was obtained with IgM specific antibody to Phase- 2 antigen. The proportion of patients possessing these antibodies increases rapidly during the next 7 days and by day 14 , all had developed IgM specific antibody to Phase- 2 antigen, $65-80 \%$ had IgM Phase-1, IgG Phase-2, and IgA Phase- 2 antibody and $70 \%$ had CF Phase- 2 antibody. By day 21 , all patients not only had Phase- 2 IgM and Phase- 1 IgM specific antibodies, but $85-94 \%$ also possessed IgG, IgA and CF antibodies to Phase- 2 antigen. By day 28 all patients had IgM Phase-1 specific antibody, together with IgM, IgG and CF antibodies to Phase- 2 antigen; $90 \%$ of patients had $\operatorname{IgA}$ antibody to Phase 2 at this stage. The antibody response to Phase- 1 antigen, with the exception of Phase-1 IgM, is slow; Phase-1 IgG and IgA appearing 22-28 days after onset of illness and Phase-1 CF antibodies in 29-35 days. After 4 months, $50 \%, 66 \%$ and $80 \%$ of patients had developed Phase-1 CF, IgA and IgG antibody respectively.

Although the presentation of the data as a proportion of sera from patients that were positive at or above the starting dilution of the serum used in the tests, and at particular stages of the disease, gives a clear idea of the kinetics of the antibody response, it does not give any insight into the levels of antibody attained. Examples of the titres of $\operatorname{IgM}$, IgA, IgG specific and CF antibodies present in sequential sera from three patients (A, B and C) after acute $\mathrm{Q}$ fever are shown in table III. In these three patients the familiar pattern of a CF-antibody response to $\mathrm{Q}$ fever Phase- 2 antigen alone is clearly evident. By contrast, IF-IgM specific antibody is present to both 
TABLE III

Pattern of development and persistence of Phase-I and Phase-2 complement-fixing and immunofuorescent antibody to $C$. burneti following acute $Q$ fever

\begin{tabular}{|c|c|c|c|c|c|c|c|c|c|}
\hline \multirow[b]{4}{*}{ Patient } & \multirow{4}{*}{$\begin{array}{l}\text { Days } \\
\text { after } \\
\text { onset of } \\
\text { illness }\end{array}$} & \multicolumn{8}{|c|}{ Antibody titres measured by } \\
\hline & & \multirow{2}{*}{\multicolumn{2}{|c|}{$\begin{array}{l}\text { Complement } \\
\text { fixation }\end{array}$}} & \multicolumn{6}{|c|}{ Immunofluorescence } \\
\hline & & & & \multicolumn{2}{|c|}{ IgM } & \multicolumn{2}{|c|}{ IgG } & \multicolumn{2}{|c|}{ IgA } \\
\hline & & $\mathrm{Ph} .1$ & $\mathrm{Ph} .2$ & Ph.1 & $\mathrm{Ph} .2$ & $\mathrm{Ph} .1$ & $\mathrm{Ph} .2$ & $\mathrm{Ph} .1$ & $\mathrm{Ph} .2$ \\
\hline A & $\begin{array}{r}5 \\
53 \\
84 \\
140 \\
287 \\
339 \\
678\end{array}$ & $\begin{array}{r}<10 \\
10\end{array}$ & $\begin{array}{l}<5 \\
80 \\
80 \\
40 \\
10 \\
10 \\
20\end{array}$ & $\begin{array}{r}<10 \\
1280 \\
640 \\
320 \\
320 \\
160 \\
80\end{array}$ & $\begin{array}{r}<10 \\
1280 \\
640 \\
160 \\
160 \\
160 \\
40\end{array}$ & $\begin{array}{r}<10 \\
<10 \\
10 \\
20 \\
160 \\
40 \\
80\end{array}$ & $\begin{array}{r}<10 \\
640 \\
320 \\
80 \\
80\end{array}$ & $\begin{array}{r}<10 \\
<10 \\
20 \\
20 \\
20 \\
20 \\
20\end{array}$ & $\begin{array}{r}<10 \\
<10 \\
40 \\
40 \\
20 \\
20 \\
10\end{array}$ \\
\hline B & $\begin{array}{r}12 \\
42 \\
63 \\
124 \\
207 \\
396 \\
572\end{array}$ & $\begin{array}{l}<10 \\
<10 \\
10 \\
<20 \\
<20 \\
<10 \\
<10\end{array}$ & $\begin{array}{r}<5 \\
320 \\
1280 \\
160 \\
80 \\
20 \\
20\end{array}$ & $\begin{array}{r}10 \\
160 \\
160 \\
40 \\
20 \\
<10 \\
<10\end{array}$ & $\begin{array}{r}40 \\
640 \\
320 \\
80 \\
80 \\
80 \\
40\end{array}$ & $\begin{array}{r}<10 \\
10 \\
40 \\
80 \\
20 \\
<10 \\
<10\end{array}$ & $\begin{array}{r}20 \\
1280 \\
5120 \\
1280 \\
640 \\
80 \\
80\end{array}$ & $\begin{array}{r}<10 \\
<10 \\
<10 \\
10 \\
10 \\
<10 \\
<10\end{array}$ & $\begin{array}{r}10 \\
40 \\
160 \\
40 \\
40 \\
20 \\
20\end{array}$ \\
\hline $\mathrm{C}$ & $\begin{array}{r}11 \\
55 \\
102 \\
197 \\
368 \\
543 \\
613\end{array}$ & $\begin{array}{l}<10 \\
<10 \\
<10 \\
<10 \\
<10 \\
<10 \\
<10\end{array}$ & $\begin{array}{r}>320 \\
320 \\
80 \\
40 \\
20 \\
10 \\
10\end{array}$ & $\begin{array}{r}10 \\
160 \\
40 \\
10 \\
10 \\
10 \\
<10\end{array}$ & $\begin{array}{r}10240 \\
5120 \\
640 \\
160 \\
80 \\
40 \\
40\end{array}$ & $\begin{array}{r}<10 \\
<20 \\
80 \\
160 \\
160 \\
80 \\
80\end{array}$ & $\begin{array}{r}320 \\
5120 \\
1280 \\
1280 \\
320 \\
320 \\
320\end{array}$ & $\begin{array}{r}<10 \\
40 \\
40 \\
40 \\
20 \\
20 \\
20\end{array}$ & $\begin{array}{r}1280 \\
5120 \\
320 \\
320 \\
80 \\
40 \\
40\end{array}$ \\
\hline
\end{tabular}

Phase- 1 and -2 antigens by $42-55$ days after onset of illness, while the Phase- $1 \mathrm{CF}$ antibody is still negative. IF-IgG specific antibody develops to Phase-2 antigen with much the same speed as $\operatorname{IgM}$ specific antibody to Phases 1 and 2, but $\operatorname{IgG}$ specific antibody to Phase 1 rises more slowly. IF-IgA specific antibody to the two antigen phases mirrors that in the IgG fraction and is not remarkable except to note the high IgA antibody titre in patient C (see Peacock et al., 1983, and Discussion). Finally, the late appearance of $\mathrm{IgG}$ and IgA antibody to Phase-1 antigen may allow the demonstration of a four-fold or greater increase in titre between paired sera even when the first serum sample is taken as late as 3-4 weeks after onset of illness. It should be noted that the IgM specific antibody to both Phase- 1 and -2 antigens declines after 2--3 months but low levels (titre of 40 ) may be present 600 or more days after onset of illness.

\section{Immunoglobulin class and the complement-fixing antibody response in acute $Q$ fever}

Traditionally, antigenic phase variation in $C$. burneti has been recognised by the $\mathrm{CF}$ reactions of sera from infected guinea-pigs - those taken early in convalescence react with high-passage-level egg-adapted Phase- 2 antigen while those taken in late convalescence react with both Phase- 1 and -2 antigens. Sera from early convalescent human $\mathrm{Q}$ fever cases react well in the CFT with Phase- 2 antigen and rarely or at low titre with Phase-1 antigen (table III). However, human subjects clearly have the 
TABLE IV

Complement-fixing (CF) and immunofluorescence (IF) activity of unfractionated and IgM fractions from early convalescent-phase sera from four patients with acute $Q$ fever

\begin{tabular}{|c|c|c|c|c|c|c|c|c|c|c|c|c|}
\hline \multirow{4}{*}{$\begin{array}{l}\text { Patient } \\
\text { (day of } \\
\text { illness) }\end{array}$} & \multicolumn{12}{|c|}{ Antibody titre of } \\
\hline & \multicolumn{4}{|c|}{ Unfractionated serum } & \multicolumn{8}{|c|}{ Fractionated serum } \\
\hline & \multicolumn{2}{|c|}{ Phase 1} & \multicolumn{2}{|c|}{ Phase 2} & \multicolumn{2}{|c|}{$\begin{array}{l}\text { Fraction } \\
\text { Phase } 1\end{array}$} & \multicolumn{2}{|c|}{$\begin{array}{l}2, \text { IgM } \\
\text { Phase } 2\end{array}$} & \multicolumn{2}{|c|}{$\begin{array}{l}\text { Fraction } \\
\text { Phase } 1\end{array}$} & \multicolumn{2}{|c|}{$\begin{array}{r}2, \mathrm{IgG} / \mathrm{A} \\
\text { Phase } 2\end{array}$} \\
\hline & $\mathrm{CF}$ & IgM-IF & $\mathrm{CF}$ & IgM-IF & $\mathrm{CF}$ & IgM-IF & $\mathrm{CF}$ & IgM-IF & $\mathrm{CF}$ & IF & $\mathrm{CF}$ & IF \\
\hline $\begin{array}{l}\mathrm{Du} \\
(31)\end{array}$ & $<5$ & 80 & 320 & 640 & $<8$ & 16 & 128 & 256 & $\ldots$ & $<8$ & $\ldots$ & $<<$ \\
\hline $\begin{array}{l}\text { St } \\
(36)\end{array}$ & $<5$ & $>2048$ & 160 & 8 & $<8$ & 128 & $<8$ & 16 & $\ldots$ & $<8$ & $\ldots$ & $<8$ \\
\hline $\begin{array}{l}\mathrm{Da} \\
(15)\end{array}$ & $<5$ & 20 & 160 & 5120 & $<16$ & 16 & 64 & 256 & $\ldots$ & $<8$ & $\ldots$ & $<8$ \\
\hline $\begin{array}{l}\mathrm{He} \\
(20)\end{array}$ & $<5$ & 32 & $>320$ & 2048 & 128 & 32 & 128 & 4096 & $\ldots$ & $<8$ & $\ldots$ & $<8$ \\
\hline
\end{tabular}

capacity to form IgM antibody to Phase-1 antigen early in the course of acute Q fever and this binds to the organism as demonstrated by immunofluorescence (table III). This is surprising because accepted immunological principles indicate that whereas two or more IgG molecules bound to antigenic determinants in close proximity are required to generate a complement-fixing complex, a single molecule of IgM when bound to antigen can fix complement (Borsos et al.,1981). However, the observations described so far relate to whole serum tested on separate occasions by CF or IF. As a first step in the investigation of the paradox, CF and IF titrations were done on separated immunoglobulin fractions. Early convalescent-phase sera from four $Q$ fever patients containing IgM specific antibody to Phase- 1 and -2 antigens were treated to remove $\mathrm{RF}$ and fractionated on sucrose density gradients. The isolated fractions were checked by radial immunodiffusion to confirm specific separation, then titrated by $\mathrm{CF}$ and IF with $C$. burneti Phase- 1 and -2 antigens.

Table IV confirms that the unfractionated sera did not react by CF with Phase-1 antigen. However, although the separated IgM fractions of the sera from patients $\mathrm{Du}$, St and Da did not react in the CFT with Phase-1 antigen, the serum from the fourth patient, $\mathrm{He}$, reacted after fractionation but not before. The IgM fractions from patients $\mathrm{Du}, \mathrm{Da}$ and $\mathrm{He}$ reacted with Phase-2 antigen (see Discussion) but that of patient St, which was positive at a dilution of 1 in 16 by IF, was undetectable by CF.

\section{Pattern of CF and IF antibody response in chronic $Q$ fever}

Serum samples were available from nine patients with suspected or proven chronic $\mathrm{Q}$ fever. Eight of the patients (Vi, De, Br, Qu, Wi, Re, Wy, Di) were considered to have $Q$ fever endocarditis on the basis of clinical evidence of valvular disease and high levels of complement-fixing antibodies to $C$. burneti, Phase- 1 and -2 antigens. In two of this group, the rickettsia was demonstrated in the heart valve vegetations; in Wy by isolation of the organism in guinea-pigs and in Di by indirect immunofluorescence and Giemsa staining of sections of aortic valve vegetations.

The remaining patient, Fo, had a chronic illness, recurrent chest pain, malaise, 
TABLE V

Complement fixing and immunofluorescence antibody to C. burneti Phase-1 and -2 antigens in nine patients with chronic $Q$ fever

\begin{tabular}{|c|c|c|c|c|c|c|c|c|c|}
\hline \multirow[b]{4}{*}{ Patient } & \multirow{4}{*}{$\begin{array}{c}\text { Date of } \\
\text { serum }\end{array}$} & \multicolumn{8}{|c|}{$\begin{array}{c}\text { Titre of antibody to } C \text {. burneti } \text { Phase- } 1 \text { and }-2 \text { antigens } \\
\text { measured by }\end{array}$} \\
\hline & & \multirow{2}{*}{\multicolumn{2}{|c|}{$\begin{array}{l}\text { complement } \\
\text { fixation }\end{array}$}} & \multicolumn{6}{|c|}{ immunofluorescence } \\
\hline & & & & \multicolumn{2}{|c|}{$\operatorname{IgM}$} & \multicolumn{2}{|c|}{ IgG } & \multicolumn{2}{|c|}{$\operatorname{IgA}$} \\
\hline & & $\mathrm{Ph} .1$ & $\mathrm{Ph} .2$ & Ph.1 & $\mathrm{Ph} .2$ & $\mathrm{Ph} .1$ & $\mathrm{Ph} .2$ & Ph. 1 & $\mathrm{Ph} .2$ \\
\hline Fo & $\begin{array}{r}21.4 .81 \\
7.9 .81 \\
25.1 .82\end{array}$ & $\begin{array}{l}2560 \\
1280 \\
1280\end{array}$ & $\begin{array}{l}640 \\
320 \\
320\end{array}$ & $\begin{array}{l}<10 \\
<10 \\
<10\end{array}$ & $\begin{array}{l}<10 \\
<10 \\
<10\end{array}$ & $\begin{array}{r}>10240 \\
20480 \\
40960\end{array}$ & $\begin{array}{r}2560 \\
2560 \\
160\end{array}$ & $\begin{array}{l}10240 \\
10240 \\
10240\end{array}$ & $\begin{array}{r}2560 \\
640 \\
640\end{array}$ \\
\hline $\mathrm{Vi}$ & $\begin{array}{l}9.1 .78 \\
1.5 .78 \\
6.3 .79\end{array}$ & $\begin{array}{l}640 \\
640 \\
640\end{array}$ & $\begin{array}{l}640 \\
640 \\
640\end{array}$ & $\begin{array}{r}<10 \\
80 \\
20\end{array}$ & $\begin{array}{l}10 \\
10 \\
20\end{array}$ & $\begin{array}{l}10240 \\
10240 \\
10240\end{array}$ & $\begin{array}{l}81920 \\
40960 \\
40960\end{array}$ & $\begin{array}{r}1280 \\
1280 \\
320\end{array}$ & $\begin{array}{r}2560 \\
2560 \\
640\end{array}$ \\
\hline $\mathrm{De}$ & $\begin{array}{r}18.3 .80 \\
9.4 .80\end{array}$ & $\begin{array}{l}640 \\
640\end{array}$ & $\begin{array}{l}640 \\
640\end{array}$ & $\begin{array}{l}<10 \\
<10\end{array}$ & $\begin{array}{l}<10 \\
<10\end{array}$ & $\begin{array}{l}40960 \\
81920\end{array}$ & $\begin{array}{l}40960 \\
81920\end{array}$ & $\begin{array}{l}10240 \\
20480\end{array}$ & $\begin{array}{l}320 \\
640\end{array}$ \\
\hline $\mathrm{Br}$ & N.K. & $>320$ & 320 & $<10$ & $<10$ & 10240 & 320 & 640 & 20 \\
\hline $\mathrm{Qu}$ & N.K. & 320 & 320 & $<10$ & $<10$ & $>20480$ & 2560 & 5120 & 160 \\
\hline $\mathrm{Wi}$ & $\begin{array}{r}10.11 .77 \\
4.1 .78\end{array}$ & $\begin{array}{l}320 \\
320\end{array}$ & $\begin{array}{l}320 \\
320\end{array}$ & $\begin{array}{l}<10 \\
<10\end{array}$ & $\begin{array}{l}<10 \\
<10\end{array}$ & $\begin{array}{r}20480 \\
>81920\end{array}$ & $\begin{array}{l}320 \\
320\end{array}$ & $\begin{array}{l}1280 \\
5120\end{array}$ & $\begin{array}{r}80 \\
160\end{array}$ \\
\hline $\operatorname{Re}$ & 23.8 .74 & 640 & 320 & $<10$ & $<10$ & $>81920$ & 320 & 20480 & 640 \\
\hline & 22.10 .74 & 640 & 320 & $<10$ & $<10$ & $>81920$ & 640 & 20480 & 320 \\
\hline $\mathrm{Wy}^{*}$ & $\begin{array}{r}1.8 .83 \\
4.1 .83 \\
12.1 .84\end{array}$ & $\begin{array}{l}640 \\
320 \\
160\end{array}$ & $\begin{array}{l}320 \\
320 \\
160\end{array}$ & $\begin{array}{l}<10 \\
<10 \\
<10\end{array}$ & $\begin{array}{r}20 \\
<10 \\
<10\end{array}$ & $\begin{array}{l}32768 \\
20480 \\
10240\end{array}$ & $\begin{array}{l}20480 \\
10240 \\
20480\end{array}$ & $\begin{array}{r}81920 \\
5120 \\
5120\end{array}$ & $\begin{array}{l}5120 \\
5120 \\
5120\end{array}$ \\
\hline $\mathrm{Di}^{*}$ & 14.6 .82 & 1280 & 1280 & 40 & 20 & 2560 & 1280 & 1280 & 320 \\
\hline
\end{tabular}

sweating and gross haematuria. This followed a $\mathrm{Q}$ fever-like illness a year before. On investigation he had a raised ESR, raised aminotransferases and small pleural effusions. A liver scan and echocardiogram did not reveal pathological changes but an IVP showed chronic pyelonephritis. A renal biopsy showed glomerulonephritis with IgM and bound complement. The diagnosis was chronic $Q$ fever but clear evidence of endocarditis has not been obtained so far and the site of infection is uncertain. The patient has improved clinically on a prolonged course of rifampicin, with falling ESR and liver enzymes returning to normal limits.

Table V shows the CF and IF antibody titres in this group of patients. All have the well recognised pattern of elevated CF antibody to both Phase- 1 and Phase- 2 antigens first described by Andrews and Marmion (1959). The CF antibody results are mirrored by the very high IgG specific IF antibody titres to the two antigens. On the other hand, IgM specific antibody is absent from most sera, or only present at low titre (10-80). Sera from chronic $Q$ fever patients frequently contain $\mathrm{RF}$ and particular care has to be taken to remove this before testing (see comments on Kimbrough et al., 1979 in Discussion).

Finally, in contrast to acute cases of $\mathrm{Q}$ fever which not infrequently show raised IgA specific antibody to Phase- 2 antigen, all sera from the chronic cases showed 
TABLE VI

Specificity of $\lg A$ antibody to $C$. burneti Phase-1 and -2 antigens in patients with chronic $Q$ fever

\begin{tabular}{|c|c|c|c|c|c|c|c|c|c|c|c|}
\hline \multirow[b]{3}{*}{ Patient } & \multirow{3}{*}{$\begin{array}{c}\text { Sucrose } \\
\text { fraction } \\
\text { no. }\end{array}$} & & \multirow{2}{*}{\multicolumn{3}{|c|}{$\begin{array}{l}\text { Radial } \\
\text { immunodiffusion }\end{array}$}} & \multicolumn{6}{|c|}{$\begin{array}{l}\text { Titre of antibody to } C \text {. burneti by } \\
\text { immunofluorescence }\end{array}$} \\
\hline & & & & & & \multicolumn{2}{|c|}{ IgM } & \multicolumn{2}{|c|}{$\mathrm{IgG}$} & \multicolumn{2}{|c|}{ IgA } \\
\hline & & & $\operatorname{IgM}$ & $\mathrm{IgG}$ & $\operatorname{IgA}$ & $\mathrm{Ph} .1$ & $\mathrm{Ph} .2$ & $\mathrm{Ph} .1$ & $\mathrm{Ph} .2$ & $\mathrm{Ph} .1$ & $\mathrm{Ph} .2$ \\
\hline Wy & 11 & $\begin{array}{l}\text { unadsorbed } \\
\text { adsorbed }\end{array}$ & - & ++ & ++ & $<16$ & $<16$ & 8192 & 512 & 512 & 512 \\
\hline Fo & 11 & $\begin{array}{l}\text { anti IgG } \\
\text { unadsorbed } \\
\text { adsorbed }\end{array}$ & - & + & $\begin{array}{l}++ \\
++\end{array}$ & $\begin{array}{l}<16 \\
<20\end{array}$ & $\begin{array}{l}<16 \\
<20\end{array}$ & $\begin{array}{l}<16 \\
5120\end{array}$ & $\begin{array}{r}<16 \\
640\end{array}$ & $\begin{array}{r}4096 \\
640\end{array}$ & $\begin{array}{r}1024 \\
320\end{array}$ \\
\hline & & anti-IgG & - & - & ++ & $<20$ & $<20$ & $<20$ & $<20$ & 640 & 320 \\
\hline
\end{tabular}

substantial levels of IgA specific antibody to Phase- 1 antigen-a finding also noted by Peacock et al. (1983) (see Discussion). RF occurs in all three immunoglobulin classes, including IgA (Abraham et al., 1972). Consequently the possibility was investigated that IgA specific antibody reactivity observed in the chronic $Q$ fever patients was, in fact, a complex of IgA RF with IgG specific antibody. IgG-IgA fractions were isolated from patients $\mathrm{Wy}$ and Fo and tested by immunofluorescence before and after multiple absorptions with anti-IgG. The IgG specific antibody detected by IF was removed but the titre of IgA antibody was unaltered or increased (table VI).

Pattern of CF and IF antibody responses in subjects given $Q$-fever vaccine or skin tested for $Q$ fever immunity

In a trial of Q-fever vaccine to control abattoir-associated $\mathrm{Q}$ fever, volunteer subjects were given one subcutaneous injection of $30 \mu \mathrm{g}$ of inactivated Henzerling Phase-1 rickettsiae or skin tested by intradermal injection of diluted vaccine containing $0.02 \mu \mathrm{g}$ of rickettsiae (Marmion et al., 1984). The observations on the serological responses are divided into three groups: (a) 147 subjects who were seronegative (no $\mathrm{CF}$ antibody at a dilution of 1 in $2 \cdot 5$, or IgM, IgG or IgA IF antibody at a dilution of 1 in 10) before vaccination; (b) 39 subjects who had equivocal, low levels of CF or IF antibody to Phase- 1 or Phase- 2 antigens or both of $C$. burneti and a negative skin test before vaccination; and (c) 93 subjects who were skin-test positive and were sampled subsequently to detect a booster effect of the skin test antigen. About $70 \%$ of the latter subjects also had antibody in the pre-skin test serum. Pre- and post-vaccination and skin test sera from the three groups were tested for CF and IgM, IgG and IgA specific antibody to Phase- 1 and -2 antigens.

Fig. 2 shows the results obtained in terms of the proportion of those sampled who seroconverted by one or more of the four serological tests used. Seroconversion was defined as a four-fold or greater increase in antibody titre between pre- and post-vaccination or skin test sera; non conversion (NC) was taken as either no change or a two-fold increase in antibody titre.

In the 147 subjects who were negative before vaccination the most frequent response was the formation of IF IgM specific antibody to Phase- 1 antigen and a lower frequency of $\mathrm{CF}$, IgM and IgG specific antibody responses to Phase-2; IgA specific 
SERONEGATIVE BEFORE VACCINATION

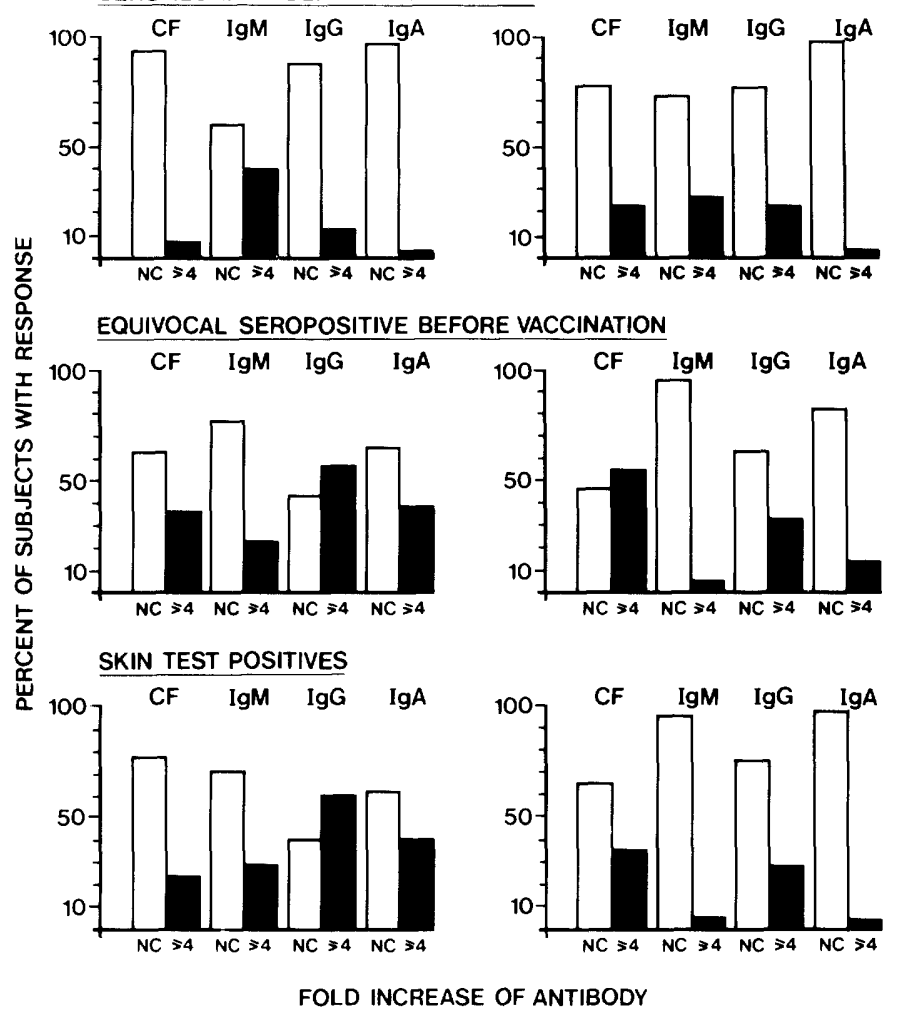

FIG. 2.-Frequency of complement-fixing and immunoglobulin-class specific antibody responses to $C$. burnet $P$ Phase- 1 and Phase-2 antigens among $Q$ fever vaccinated or skin tested subjects with and without evidence of previous exposure to infection, $\mathrm{NC}=$ no change.

antibody was essentially negative. In the 39 subjects with equivocal antibody titres before vaccination, or in the 93 subjects with a positive skin test, the reactions were similar, namely a marked IgG specific antibody response to Phase-1 and Phase-2 antigens and only about $5 \%$ showed IgM specific antibody to Phase- 2 antigen. There was also a more marked CF response to Phase- 2 antigen. It was concluded from the pattern in the former that equivocal levels of prevaccination antibody do, in fact, represent immunity.

\section{Discussion}

In man, the major antibody response in early convalescence from acute $Q$ fever is directed against $C$. burnet $i$ Phase- 2 antigen; it is detected by complement fixation and by immunofluorescence and is present in the $\operatorname{IgM}, \operatorname{IgG}$ and IgA fractions. The Phase-2 IF IgM specific antibody appears rapidly and sometimes together with $\operatorname{IgG}$ and $\operatorname{IgA}$ specific antibodies may be present in some patients at around 14 days after onset of illness, before CF antibody has developed. This has obvious diagnostic advantages. IF-IgM antibodies against Phase-1 antigen also develop early and preliminary experiments reported here show that the majority of these have the unusual property of not fixing complement. 
The failure of IgM antibody to fix complement with Phase- 1 antigen runs contrary to commonly-held immunological tenets on its high complement-fixing ability, although virologists have recognised for some time that some IgG subclasses, rather than IgM, make the major contribution to complement fixation in viral antigen-antibody systems (Cowan, 1973). The failure of complement fixation might be related to variations in the complement-fixing ability of subpopulations of IgM molecules; Harboe and Folling (1974) have recognised two distinct groups of human IgM and IgA based on extent of binding to the Cowan 1 strain of $S$. aureus. These are of uncertain functional significance. Alternatively, and more probably, the effect might be related to the density of antigenic determinants on the Phase-1 antigen compared with those on Phase-2 antigen. Borsos et al. (1981) studied complement fixation and lysis in a model system of naturally occurring human $\operatorname{IgM}$ anti-methotrexate and anti-folinic acid antibodies and sheep erythrocytes coated with these haptens. At low hapten densities, IgM was bound but did not bind complement; at higher hapten densities it bound complement and activated lysis.

An IgA antibody response to Phase- 2 antigen was detected in $90 \%$ of sera from patients with acute $Q$ fever and was shown to have activity free from IgM or IgG; thus it did not appear to be either a complex of IgA rheumatoid factor and specific antibody or a hybrid IgM-A molecule of the type described by Kearney (1983) in mice immunised against pneumococcal polysaccharide. The late rise (3-4 weeks after onset of illness) of Phase-1 IgG specific antibody offers a good chance of demonstrating a four-fold or greater increase of antibody related to a recent infection when, in other respects, the convalescent sera present an unchanging antibody level. IgM specific antibody was shown to persist for at least 678 days after infection although at low levels. An association of the latter with IgG or IgA antibody against Phase-1 antigen reinforces the notion of a past rather than a current infection. Our results with acute cases of $Q$ fever differ from those of Peacock et al. (1983) who did not detect IgA specific to Phase- 2 in five patients with acute (primary) $Q$ fever. The reason for the discrepancy is not apparent.

In chronic $Q$ fever and $Q$ fever endocarditis the serological pattern shows two marked differences from that in the acute disease. First, the IgM antibodies to Phase-1 and Phase- 2 antigens were present at low titre or completely absent. This pattern of antibody response was also reported by Peacock et al. (1983) although Kimbrough et al. (1979) observed substantial levels of IgM specific antibody to Phases 1 and 2. It is presumed that the effect was due to the presence of IgM RF. We have found that such sera have to be absorbed several times with $\gamma$-globulin-coated latex particles to remove $\mathrm{RF}$ and to avoid false positive IgM results. When sucrose density gradient fractions of the sera containing IgM from our chronic $Q$ fever cases were tested for specific IgM antibody, only low or undetectable levels of specific IgM antibodies were found, which confirmed the findings for whole sera and excluded the possibility that the very high levels of the more avid Phase- 1 and Phase- 2 IgG and IgA antibodies were blocking the attachment of the IgM antibody. The interference with $\operatorname{IgM}$ specific titres to C. burneti due to RF, in patients with the chronic form of the disease, manifested as granulomatous hepatitis or endocarditis or both, was also noted by Peacock et al. (1983). Second, we confirm the findings of the latter authors that high levels of IgA specific antibody to Phase-1 are present in chronic $Q$ fever. However, it seems doubtful whether this particular immune marker offers any diagnostic advantage over the conventional demonstration of high levels of CF antibody to Phase-1 antigen. 
In the trials of $\mathrm{Q}$ fever vaccine in abattoir workers it was found that the predominant antibody response in $40 \%$ of vaccinees who were seronegative and skin-test negative before vaccination was an IgM antibody to the Phase- 1 antigen of $C$. burneti. Antibody to the Phase- 2 antigen was detected as IgM and IgG immunoglobulin in $26 \%$ and $24 \%$ of subjects respectively and was detectable by the complement fixation test in $24 \%$ of vaccinees. The presence of Phase- 1 and Phase- 2 antibodies after vaccination was reported by Fiset et al. (1969) who detected it by the microagglutination test. In our series, where the majority of workers were sampled between 10 and 120 days after vaccination, the overall conversion rate by any one or more of the serological tests among 225 vaccinees without evidence of humoral immunity before vaccination, was $65.3 \%$. Not unexpectedly, skin test negative volunteers who possessed humoral antibody in their pre-vaccination sera but were vaccinated responded more vigorously to vaccination ("booster effect"), with $88.6 \%$ seroconverting. The pattern of antibody response was similar to that shown for a group of 93 individuals, 71 $(76 \cdot 1 \%)$ of whom also possessed evidence of humoral immunity in their sera before being positive in the skin tests. The highest frequency of antibody titre increases between pre- and post-vaccination or positive skin test sera in these two groups was in the IgG fraction and to the Phase- 1 antigen. With the Phase- 2 antigen it was most often detected by the CF test and in the IgG fractions; however good responses to the Phase- 1 antigen were also detected in the $\operatorname{IgA}$ and $\operatorname{IgM}$ fractions and to a lesser degree by the CF test.

Ninety percent of 93 volunteers who were skin test positive, but not vaccinated, seroconverted. Other authors have reported similar findings. Serological conversion following skin testing and vaccination was also detected by the CF test, using a Phase-2 antigen, in $92.8 \%$ of previously immunised individuals and $96.4 \%$ of persons naturally infected in the past (Cracea et al., 1977). In a similar group of immunised or naturally infected individuals, studied by Peacock et al. (1979), who displayed a positive skin reaction to a small dose of Phase-1 vaccine, all subjects showed a strong response to the Phase- 1 antigen which was detectable by micro-agglutination but not by the CF test; 11 out of 16 reactors also gave a moderate agglutinin response and six a CF response to Phase- 2 antigen. In our study of positive skin test reactors, $23 \%$ of 93 subjects developed CF antibody to the Phase- 1 antigen and $34 \%$ developed CF antibody to the Phase-2 antigen. This is in agreement with the findings of Bell et al. (1964) who showed that antibody to the Phase- 1 or -2 antigens or to both, detectable by the CF test, developed subsequently in subjects following positive skin tests.

The pattern and magnitude of all responses following vaccination or skin testing of both immune and non-immune was distinguishable from that observed in clinical $Q$ fever and vaccination does not complicate the serodiagnosis of clinical Q fever.

We are indebted to Dr M. Kyrkou and Sister P. Mitchell at the South Australian Meat Corporation for the collection of specimens and information about vaccination histories, and to the Medical Practitioners of South Australia who submitted blood samples and clinical notes from acute cases of Q fever. We are also grateful to Mrs D. Mauviel for typing the manuscript.

\section{REFERENCES}

Abinanti F R, Marmion B P 1957 Protective or neutralizing antibody in Q fever. American Journal of Hygiene 66: 173-195. 
Abraham G N, Clark R A, Vaughan J H 1972 Characterization of an IgA rheumatoid factor: binding properties and reactivity with the subclasses of human $\gamma \mathrm{G}$ globulin. Immunochemistry 9: 301-315.

Andrews P S, Marmion B P 1959 Chronic Q fever. 2. Morbid anatomical and bacteriological findings in a patient with endocarditis. British Medical Journal 2: 983-988.

Babudieri B 1958 Studies on the microscopic slide-agglutination test for Q fever. Bulletin of the World Health Organisation 19: 981-994.

Bell J F, Luoto L, Casey M, Lackman D B 1964 Serologic and skin-test response after Q fever vaccination by the intracutaneous route. The Journal of Immunology 93: 403-408.

Borsos T, Chapuis R M, Langone J J 1981 Distinction between fixation of $\mathrm{Cl}$ and the activation of complement by natural IgM anti-hapten antibody: effect of cell surface hapten density. Molecular Immunology 18: 863-868.

Bozeman F M, Elisberg B L 1963 Serological diagnosis of scrub typhus by indirect immunofluorescence. Proceedings of the Society for Experimental Biology and Medicine 112: $568-573$.

Bradstreet C M P, Taylor C E D 1962 Technique of complement-fixation test applicable to the diagnosis of virus diseases. Monthly Bulletin of the Ministry of Health and the Public Health Laboratory Service 21: 96-104.

Buckley B 1980 Q fever epidemic in Victorian general practice. Medical Journal of Australia: 593-595.

Cowan K M 1973 Antibody response to viral antigens. Advances in Immunology 17: 195-253.

Cracea E, Dumitrescu-Constantinescu S, Botez D, Ioanid L 1977 Q-fever soluble vaccine effects in Coxiella burneti sensitised humans. Zentralblatt für Bakteriologie Mikrobiologie und Hygiene, 1. Abt Orig A. 238: 413-418.

Elisberg B L, Bozeman F L 1966 Serological diagnosis of rickettsial diseases by indirect immunofluorescence. Archives de l'Institut Pasteur de Tunis 43: 193-204.

Field P R, Hunt J G, Murphy A M 1983 Detection and persistence of specific IgM antibody to Coxiella burnetii by enzyme-linked immunosorbent assay: A comparison with immunofluorescence and complement-fixation tests. Journal of Infectious Diseases 148: 477-487.

Fiset P, Ormsbee R A, Silberman R, Peacock M, Spielman S H. 1969 A microagglutination technique for detection and measurement of rickettsial antibodies. Acta Virologica 13: 60-66.

Giroud P, Giroud M L 1944 Agglutination des rickettsies, test de séro-protection et réaction d'hypersensibilité cutanée. Bulletin de la Societe de Pathologie Exotique 37: 84-93.

Goldwasser R A, Shepard C C 1959 Fluorescent antibody methods in the differentiation of murine and epidemic typhus sera; specificity changes resulting from previous immunization. Journal of Immunology 82: 373-380.

Halevy M, Goldwasser R A 1972 Differentiation of Phase I and Phase II Coxiella burneti by means of fluorescent antibody techniques. Israel Journal of Medical Science 8: 583-587.

Halle S, Dasch G A, Weiss E 1977 Sensitive enzyme-linked immunosorbent assay for detection of antibodies against typhus rickettsiae, Rickettsia prowazekii and Rickettsia typhi. Journal of Clinical Microbiology 6: 101-110.

Harboe M, Folling I 1974 Recognition of two distinct groups of human IgM and IgA based on different binding to staphylococci. Scandinavian Journal of Immunology 3: 471-482.

Hunt J G, Field P R, Murphy A M 1983 Immunoglobulin responses to Coxiella burnetii (Q fever): single-serum diagnosis of acute infection, using an immunofluorescence technique. Infection and Immunity 39: 977-981.

Kearney R 1983 Binding of murine IgM and monoclonal IgM/A(k) hybrid anti-type III pneumococcal polysaccharide (SIII) antibodies to staphylococcal protein A. Australian Journal of Experimental Biology and Medical Science 61: 91-104.

Kimbrough R C, Ormsbee R A, Peacock M, Rogers W R, Bennetts R W, Raaf J, Krause A, Gardner C 1979 Q-fever endocarditis in the United States. Annals of Internal Medicine 91: 400-402.

Lackman D B, Gilda G, Philip R N 1964 Application of the radioisotope precipitation test to the study of Q fever in man. Health Lab Science 1: 21-28.

Lennette E H, Clark W H, Jensen F W, Toomb C J 1952 Q fever studies. XV. Development and 
persistence in man of complement-fixing and agglutinating antibodies to Coxiella burnetii. Journal of Immunology 68: 591-598.

Luoto L 1956 A capillary-tube for antibody against Coxiella burnetii in human, guinea-pig and sheep sera. The Journal of Immunology 77: 294-298.

Marmion B P et al. 1984 Vaccine prophylaxis in the control of abattoir-associated Q fever. Lancet, .

McKiel J A, Millar A M 1968 Serodiagnosis in Q fever with special emphasis on the radioisotope precipitation test. Canadian Journal of Microbiology 14: 721-726.

Murphy A M, Magro L 1980 IgM globulin response in Q fever (Coxiella burneti) infections. Pathology 12: 391-396.

Murphy A M, Hunt J G 1981 Retrospective diagnosis of Q fever in a country abattoir by the use of specific IgM globulin estimations. Medical Journal of Australia 2: 326-327.

Ormsbee R A 1964 An agglutination-resuspension test for Q fever antibodies. The Journal of Immunology 92: 159-166.

Peacock M G, Fiset P, Ormsbee R A, Wisseman C L 1979 Antibody response in man following a small intradermal inoculation with Coxiella burnetii Phase 1 vaccine. Acta Virologica 23: 73-81.

Peacock M G, Philip R N, Williams J C, Faulkner R S 1983 Serological evaluation of Q fever in humans: Enhanced Phase 1 titers of immunoglobulins $\mathrm{G}$ and $\mathrm{A}$ are diagnostic for $\mathrm{Q}$ fever endocarditis. Infection and Immunity 41: 1089-1098.

Philip R N, Casper E A, Ormsbee R A, Peacock M G, Burgdorfer W 1976 Microimmunofluorescence test for the serological study of Rocky Mountain spotted fever and Typhus. Journal of Clinical Microbiology 3: 51-61.

Stoker M G P, Fiset P 1956 Phase variation of the Nine Mile and other strains of Rickettsia burneti. Canadian Jounal of Microbiology 2: 310-321.

Tabert G G, Lackman D B 1965 The radioisotope precipitation test for study of Q fever antibodies in human and animal sera. The Journal of Immunology 94: 959-965.

Tokarevich N K, Zhebrun A B, Khazenson S L, Roshchina N G 1980 Determination of immunoglobulin classes of antibodies against Coxiella burnetii by protein A from Staphylococcus aureus. Acta Virologica 24: 218-221.

Wang S-P 1971 A microimmunofluorescence method. Study of antibody response to TRIC organisms in mice. In: Nichols R L (ed) Trachomas and related disorders caused by chlamydial agents. Excerpta Medica. Amsterdam, pp 273-288. 